DOI: https://doi.org/10.18371/fp.2(42).2021.171417

УДК 636.91

\title{
МЕТОДОЛОГІЧНІ ЗАСАДИ ОЦІНКИ ЕФЕКТИВНОСТІ ДІЯЛЬНОСТІ ДЕРЖАВНИХ ПІДПРИЕМСТВ
}

\author{
ПАРАСІЙ-ВЕРГУНЕНКО Ірина Михайлівна \\ доктор економічних наук, професор, \\ професор кафедри податкового менеджменту та \\ рінансового моніторингу ДВНЗ «Київський \\ начіональний економічний університет імені Вадима Гетьмана» \\ ORCID ID: https://orcid.org/0000-0001-6506-6965 \\ e-mail: iparasiy@gmail.com
}

Анотація. $B$ статті обтрунтовано необхідність розроблення сучасної системи аналітичних індикаторів очінювання ефективністю управління об'єктами державної власності. Метою даного дослідження $\epsilon$ розроблення методологічних засад аналізу ефективності діяльності державних підприємств через визначення завдань, принципів, основних етапів такої оцінки, удосконалення системи аналітичних показників.

Ключові слова: державне підприємство, державне регулювання, державний сектор, ефективність, управління, критерії.

Постановка проблеми. Проблема удосконалення системи управління об'єктами державної власності є надзвичайно актуальною для України. Держава продовжує виступати власником значної частини економічних активів і здійснює масштабну комерційну діяльність. Проте існуюча система управління не забезпечує ефективного функціонування державного сектора. Державний сектор значно поступається приватному сектору за рівнем ефективності господарської дія-
Аннотация. $B$ cmaтье обоснована необходимость разработки современной системы аналитических индикаторов оценивания эффективности управления объектами государственной собственности. Целью данного исследования является разработка методологических основ анализа эффективности деятельности государственных предприятий путем определения задач, принципов, основных этапов такой оценки, усовершенствования системы аналитических показателей.

Ключевые слова: госудорственное предприятие, государственное регулирование, государственный сектор, эффективность, управление, критерии.

льності. При досить високому рівні витрат (адміністративних та фінансових) управління державною власністю не приносить до державного бюджету відповідних доходів.

Важливим інструментом забезпечення дієвого управління державними підприємствами $\epsilon$ моніторинг цього процесу для виявлення недоліків та своєчасного впровадження необхідного комплексу заходів. Для забезпечення комплексності та об'єктивності оцінки аналіз ефективності управління 
об'єктами державної власності здійснюється на двох рівнях: на першому безпосередньо державними підприємствами; на другому - Міністерством фінансів України, Фондом Державного майна та іншими органами, які здійснюють контроль за ефективністю використання державного майна.

В цьому контексті особливої актуальності набуває облікова інформація про фіскальні ризики, доходи, витрати, результати діяльності державних підприємств, систему мотивації персоналу, яка в умовах застосування МСФЗ суттєво залежить обраної облікової політики.

Аналіз останніх досліджень і публікацій. На сучасному етапі розвитку вітчизняної економіки пріоритетним напрямом державної політики $є$ максимізація ефективності використання державної власності, в цілях результативного функціонування державного сектору, діяльність якого спрямована на забезпечення інтересів держави та виконання своїх безпосередніх публічних функцій в інтересах свого суспільства.

Проблемам оцінювання ефективності діяльності державних підприємств присвячено наукові праці багатьох вітчизняних вчених, зокрема: М. Білик [1], О.Длугопольського [2], Т.Коляди та Н. Кузьменко [3], І. Космідайло [4], Є.Панкратьєвої [5], О.Таранич [7], В. Хомутенко та, А. Хомутенко [11] та iн.

Попри значний внесок вказаних вчених у дану проблематику й досі залишаються невирішеними питання обгрунтування об'єктивних критеріїв та релевантної системи індикаторів для формування узагальнюючої оцінки ефективності управління об'єктами державної власності.
Метою статті є розроблення методологічних засад аналізу результативності (ефективності) діяльності державних підприємств, яка має бути врахована при розробленні політики заохочення персоналу на основі нових інформаційних можливостей, які створюються в процесі запровадження МСФЗ, та з врахуванням особливостей цілей і завдань, що постають перед державними підприємствами, спрямованих та збереження та примноження державної власності.

Виклад основних результатів. Критерії визначення ефективності управління суб'єктами господарювання державного сектора економіки встановлюються $з$ метою оцінки ефективності виконання за звітний період суб'єктом управління своїх функцій, визначених відповідно до чинного законодавства.

При обгрунтуванні критеріїв ефективності діяльності державних підприємств слід враховувати їх основні ознаки:

- повне чи часткове базування на державній власності. В першому випадку держава виступає єдиним власником і постачальником капіталу. В другому випадку - це змішані підприємства, в яких державний і приватний капітал $є$ джерелом фінансування комерційних проектів, але за умови, що частка першого $є$ домінуючою i держава має можливість здійснювати стратегічне управління підприємством;

- цільове спрямування діяльності підприємства на реалізацію суспільних благ та громадської користі. Pеалізація суспільної користі, зазвичай, спрямована на зростання сукупного капіталу суспільства та може бути ни- 
зькорентабельною або взагалі збитковою [6].

Критеріями визначення ефективності управління будь-якими підприємствами є рівень значення чи відповідність виконання вимог щодо системи показників, що характеризують результати фінансово-господарської діяльності, стан використання та збереження державного майна суб'єктами господарювання державного сектора економіки, які належать до сфери повноважень суб'єктів управління.

Вирішальну роль в оцінюванні критеріїв ефективності діяльності державних підприємств відіграє позиція власника (держави) відносно цілей та завдань, які висуваються перед ними. Підсумовуючи існуючі задекларовані методичні підходи до такої оцінки та враховуючи особливі цілі функціонування державних підприємств, слід виокремити такі види ефективності: соціальна; бюджетна; економічна; цільова. В межах кожного виду ефективності мають бути встановлені відповідні показники та їх критеріальні значення, які можуть різнитися для різних підприємств залежно від цілей створення таких підприємств, їх ролі в розвитку економіки країни, стратегії їх розвитку, особливостей зовнішнього середовища, в якому функціонують підприємства тощо.

Важливим інструментом забезпечення дієвого управління державними підприємствами $€$ моніторинг цього процесу для виявлення недоліків та своєчасного впровадження необхідного комплексу заходів. 3 цих позицій заслуговує на увагу розгляд методичних положень, які закріплено в нормативно-правових актах України, 3 метою їх уточнення та удосконалення.
При формуванні системи оціночних показників для аналізу соціальної ефективності, слід враховувати, що вона включає два аспекти, зокрема соціальний ефект від функціонування підприємства для суспільства в цілому та соціальний ефект для працівників конкретного підприємства.

Перший аспект передбачає врахування виконання стратегічних планових завдань, пов'язаних зі зміною якісних характеристик покращення рівня життя населення країни і проявляється в таких показниках як зростання зайнятості населення, зниження безробіття, збільшення середнього рівня заробітної плати, кількість та якість послуг соціальної значущості, що надаються підприємством (покращення стану медичного обслуговування населення, покращення екологічної безпеки, зменшення рівня злочинності в країні, покращення соціального захисту населення, здешевлення витрат населення на відповідні послуги та підвищення їх якості - транспортні, адміністративні, соціальний захист). Слід зазначити, що даний аспект взагалі не враховується в Методичних рекомендаціях [8], що нівелює соціальні цілі створення окремих видів державних підприємств в масштабах держави. Проблема оцінки ефективності діяльності таких суспільно значущих державних підприємств пов'язана 3 тим, що виміряти результати їх діяльності (головною метою яких $є$ задоволення суспільно значущих потреб) доволі складно, а оцінка соціальної складової зводиться лише до оцінювання соціальної захищеності працівників лише на рівні підприємства.

Другий аспект соціальної ефективності передбачає підвищення рівня соціального захисту працівників дер- 
жавного підприємства, який може проявлятися у підвищенні середнього рівня заробітної плати, розширенні соціального пакету працівникам підприємства, відсутності фактів прострочки виплати заробітної плати, соціальному захисті прав працівників, покращенні корпоративної культури та умов праці тощо.

Бюджетна ефективність. Даний напрям оцінювання пов'язаний 3 виконанням плану за показником чистого прибутку державних підприємств, оскільки від цього залежить обсяг податкових відрахувань в бюджет (державний чи місцевий). Він залежить від обсягу отриманого доходу та витрат підприємства. До сум перерахованих в бюджет відносять надходження від сплати податків, зборів та обов'язкових платежів, встановлених діючим законодавством, в частині надходжень, що формують доходну частину бюджету. Також до таких надходжень належать дивіденди, що сплачуються державним підприємством власнику (державі). Тому цілком виправданим є включення до критеріїв ефективності показники виконання плану за обсягом чистого прибутку та прибутку до оподаткування.

Напряму з бюджетною ефективністю пов'язана економічна ефективність, яка корелює 3 показниками виконання бюджету в частині виконання плану за розміром чистого прибутку та відрахувань у бюджет, і визначається за загальноприйнятими методиками, що передбачають співставлення отриманого результату 3 витратами, понесеними на його отримання. Зазвичай, для такої оцінки використовуються різні показники рентабельності, проте вони не увійшли до складу критеріїв ефективності діяльності державних підприємств згідно останніх Методичних рекомендацій [8, 9], що суперечить стандартним підходам до оцінки економічної ефективності. Економічна ефективність може проявлятись також через визначення показників фінансової стійкості підприємства, які характеризують фінансову стабільність суб'єкта господарювання, що безпосередньо впливає на стабільність економіки країни в цілому. В діючих методичних рекомендаціях [8] 3 11 економічних показників 3 критерії (коефіцієнт покриття, коефіцієнт фінансової стійкості, коефіцієнт платоспроможності) припадають саме на оцінку фінансової стійкості підприємств, що фактично не відображає сутність поняття «ефективність діяльності».

Крім вище зазначених видів ефективності діяльності державних підприємств в зарубіжних країнах виділяють ще й цільову ефективність, яка фактично визначається через співставлення цілей створення окремих видів державних підприємств (зокрема унітарних та казенних) 3 фактичним досягненням поставлених цілей.

Оцінка цільової ефективності діяльності окремих підприємства, яка спрямована на реалізацію суспільних благ та громадської користі, що проявляється у зростанні сукупного капіталу суспільства, не може базуватися на показниках рентабельності, оскільки в більшості випадків діяльність таких підприємств $\epsilon$ низькорентабельною або взагалі збитковою. Оцінка цільової ефективності має здійснюватись для підприємств, що створені 3 метою виконання особливо важливих завдань та цілей державного рівня, зокрема: 
- здійснення допомоги тим значущим економічним видам діяльності, що забезпечують розвиток стратегічних напрямів економіки країни та науково-технічного прогресу;

- підтримка та розвиток тих державних підприємств, які виконують специфічні функції, зокрема спрямованих на посилення національної безпеки (військової та цивільної безпеки населення, обороноздатності країни, боротьби за стихійними лихами та пандемією). Зазвичай вони взагалі не орієнтовані на отримання прибутку, тому критерії ефективності їх діяльності визначаються якістю та повнотою виконання специфічних функцій;

- реформування та оздоровлення тих видів діяльності, секторів економіки, що перебувають у кризових умовах, проте мають важливе значення для суспільства в цілому;

- здійснення допомоги тим підприємствам, що займаються питаннями екології та їі покращенням, охороною навколишнього середовища, боротьбою 3 глобальними негативними кліматичними процесами, на виконання стратегій держави пов'язаних 3 участю у міжнародних угодах, шляхом будівництва очисних споруд, заводів 3 переробки сировини та технологічних відходів, запровадження безвідходного виробництва, розвитку альтернативних джерел енергетики тощо.

Постановою КМУ № 999 від 3 листопада 2010 р. «Про визначення критеріїв віднесення об'єктів державної власності до таких, що мають стратегічне значення для економіки і безпеки держави» [7] визначено перелік цих критеріїв. Вважаємо, що оцінка ефективності діяльності таких підприємств, має здійснювати за індивідуально встановленими показниками ефективності для кожного 3 них, 3 визначенням задач виробничого та соціального характеру.

Основними завданнями побудови системи ключових показників (критеріїв) ефективності роботи державних підприємств мають бути:

- аналіз місії та стратегії компанії, визначення стратегічних цілей i завдань та встановлення взаємозв'язку між ними;

- розроблення переліку ключових індикаторів ефективності управління державними підприємствами відповідно до стратегічних цілей компанії, а також методики їх розрахунку та визначення критеріальних значень;

- формування механізму встановлення цільових значень критеріїв ефективності;

- розроблення процедур, що забезпечують реалізацію процесу підготовки ініціатив для досягнення стратегічних цілей;

- упорядкування повноважень окремих посадових осіб відповідно до поставлених цілей функціонування державних осіб;

- узгодження показників ефективності з системою відповідальності посадових осіб за реалізацію стратегічних цілей та завдань на рівні окремих сегментів діяльності, бізнес-одиниць та бізнес-функцій;

- розроблення процедур, що забезпечують моніторинг виконання планових завдань за ключовими показниками ефективності.

Узагальнення досліджень в рамках даної проблематики дало змогу виокремити такі основні принципи побудови системи ключових показників ефективності діяльності державних підприємств: 
- комплексність оцінювання ефективності діяльності державних підприємств, враховуючи мету їх створення;

- можливість кількісного виміру показників;

- мінімальна достатність ключових показників ефективності та відсутність дублюючих показників;

- прозорість ключових показників ефективності та транспарентність облікової інформації про стан їх виконання;

- комбінування показників стратегічних цілей розвитку компанії та тактичних напрямів їх досягнення;

- можливість контролю за відхиленнями від встановлених планових значень показників;

- орієнтація на зростання фінансових та виробничих результатів діяльності державних підприємств, збереження та примноження державного майна.

Висновки. При виборі критеріїв ефективності управління держаними підприємствами запропоновано враховувати особливості їх діяльності. Це дозволить оперативно виявити недоліки в системі управління державними підприємствами і розробити пропозиції щодо підвищення ефективності їх функціонування, оскільки, незважаючи на специфічні риси та соціальноекономічну спрямованість своєї діяльності, вони повинні максимально ефективно використовувати наявні фінан- сові, матеріальні та трудові ресурси, що відповідає суспільним інтересам.

Дієвий контроль за ефективністю використання державного майна значною мірою залежить від інформаційного забезпечення управління, яке в умовах використання МСФЗ, суттєво залежить від облікової політики підприємств.

Підсумовуючи вище викладене, слід зазначити, що удосконалення методичних підходів до формування критеріїв ефективності управління державними підприємствами має відбуватись в таких напрямах:

- перелік показників та їх оціночні значення для визначення ефективності діяльності необхідно диференціювати залежно від видів державних підприємств, їх функцій та завдань;

- склад показників ефективності необхідно переглянути на предмет їх відповідності сутності поняття «ефективність», для чого пропонується включити в діючі методичні рекомендації показники рентабельності діяльності або показника «ліміт витрат на 1 грн. доходу»;

- показники ефективності діяльності мають сприяти розвитку державних підприємств, слугувати базою для планування та контролю за їх діяльністю та прийняття рішень оцінки ефективності роботи управлінського складу та мотивації їх праці.

\section{Список використаної літератури}

1. Білик М. Д. Фінансові проблеми державних підприємств. Фінанси Украӥни. 2004. №6. С.70-82.

2. Длугопольський О. Концептуальні засади функціонування державного сектору у глобалізованій економіці. Фінанси Украӥни. 2008. №4. С.11-22. 
3. Коляда Т. А., Кузьменко Н. В. Управління корпоративними правами держави: оцінка ефективності та напрями реформування. Бізнес Інформ. 2019. №8. С. $45-52$.

4. Космідайло I.В. Методичні питання оцінки ефективності управління державними підприємствами. Методичні питання оцінки ефективності управління державними підприємствами. Інвестиції: практика та досвід. 2010. №21. С.2829.

5. Панкратьєва Є.В. Про ефективність методичних підходів до аналізу фінансово-господарської діяльності державних підприємств України. Ефективна економіка. 2013. №10. С.89-91.

6. Парасій-Вергуненко І.М., Самборська-Музичко Ю.О., Гнилицька Л.В. Економічна сутність державних підприємств, їх види та класифікація. Фінанси України. 2020. №10. С. 95-111.

7. Про визначення критеріїв віднесення об'єктів державної власності до таких, що мають стратегічне значення для економіки і безпеки держави. Постанова Кабінету Міністрів України № 999 від 3 листопада 2010 p. URL: https://zakon.rada.gov.ua/laws/show/999-2010-\%D0\%BF\#Text. (дата звернення: 18.04.2021 p.)

8. Про затвердження Методичних рекомендацій застосування критеріїв визначення ефективності управління об'єктами державної власності. Наказ Міністерства економічного розвитку і торгівлі України № 253 від 15.03.2013. URL: https://zakon.rada.gov.ua/ rada/show/ v0253731-13\#Text. (дата звернення: 18.04.2021 p.)

9. Про затвердження Порядку здійснення контролю за виконанням функцій 3 управління об'єктами державної власності та критеріїв визначення ефективності управління об'єктами державної власності. Постанова КМУ № 832 від 19 червня 2007 p. URL: https://zakon.rada.gov.ua/rada/ show/v0314665-07\#Text. (дата звернення: 18.04.2021 р.)

10. Таранич О.В., Ярошенко О.П. Ефективність управління об'єктами державного сектору України. Економіка і організація управління. 2019. №1 (33). С.103109.

11. Хомутенко В.П., Хомутенко А.В. Компаративний аналіз ефективності управління об'єктами державної власності. Причорноморські економічні студії. 2019. №2 (47). С. 121-126. 